\title{
Implementasi Metode Harga Pokok Proses Dalam Perhitungan Harga Pokok Produksi Pada Usaha Batik
}

\author{
Saiful Arifin ${ }^{1)}$; Tri Irawati ${ }^{2)}$ \\ 1)2)Program Studi Sistem Informasi Akuntansi, STMIK Sinar Nusantara Surakarta \\ 1) arifinsaiful@sinus.ac.id, ${ }^{2)}$ 3irawati@sinus.ac.id
}

\begin{abstract}
The Batik is a company which produces apparel from the raw materials until the finished goods. It is called production. By the production, the company aims to produce high quality products with proper list price. Finally, the company will be able to compete with other companies. The purpose of this Last Project is to produce the application of The Computerization of Accounting System for Cost of Goods Manufacture with cost method process determine the list price so it can assist the disposal section in accounting process. The method in this research was collecting the data, including observation method, interview method, and literature technique. The process in making the application of The Computerization of Accounting System for Cost of Goods Manufacture with process costing method in Sragen used a computer with Visual Basic 6 program, MySQL, and crystal report. The result of this Last Project Report is The Computerization of Accounting System for Cost of Goods Manufacture based on Orders including goods data input, raw materials data input, labors costs data input, factory overhead data input, the transaction cost of goods, the transaction of the accounting for cost of goods manufacture and list price. It is also including the report of commodities' data, the report of labors costs data, the report of commodities data, the report of factory overhead data, and the report of the accounting for cost of goods manufacture and list price.

Keywords: Raw Material, Labor Cost, Overhead, Cost of Goods Manufacture
\end{abstract}

\section{PENDAHULUAN}

Pada perusahaan manufaktur informasi biaya sangatlah penting dalam penentuan harga pokok produksi. Berdasarkan dilihat dari fungsi pokok perusahaan manufaktur yang mengolah bahan baku menjadi produk setengah jadi maupun produk jadi maka biaya dapat diklasifikasikan biaya produksi yang meliputi biaya untuk mengolah bahan baku menjadi barang jadi untuk dijual dan biaya non produksi yang meliputi biaya pemasaran dan biaya administrasi umum. Harga pokok produksi sangatlah penting bagi perusahaan terutama untuk menentukan besarnya harga jual produk. Harga jual yang terlalu rendah akan menyebabkan kerugian bagi perusahaan, dan apabila harga jual terlalu tinggi hal yang sama juga akan terjadi karena penjualan barang akan berkurang karena harga yang kurang bersaing dipasar. Batik merupakan suatu perusahaan manufaktur yang bergerak dibidang batik. Untuk memenuhi kebutuhan pasar maka perusahaan ini menggunakan metode harga pokok proses dalam pencatatan produksinya, karena perusahaan ini memproduksi barang secara massa. Akan tetapi pencatatan biaya dan perhitungannya masih dilakukan dengan cara manual dan tidak mencatat berdasarkan departemen/ bagian-bagian produksi hal tersebut dapat mengurangi keakuratan data yang rentan akan terjadinya kesalahan yang akan mengakibatkan kerugian bagi perusahaan itu sendiri. Untuk mengatasi masalah tersebut maka diperlukan sistem dan perhitungan yang baik, agar perusahaan dapat mencapai laba yang maksimal. Dalam penjualan barang hasil produksi diperlukan penentuan harga jual yang akan ditawarkan kepada konsumen, agar tidak terjadi kerugian dalam memproduksi barang dan tidak menimbulkan kesan terlalu mahal. Maka ketepatan dalam perhitungan harga jual dan laba harus benar-benar diperhatikan. Adapun tujuan penelitian ini adalah membuat perancangan dan aplikasi harga pokok produksi dengan metode harga pokok proses pada perusahaan Batik.

\section{TINJAUAN PUSTAKA}

\subsection{Harga Pokok Produksi}

Harga pokok produksi adalah semua biaya-biaya produksi antara lain biaya bahan baku, biaya tenaga kerja, biaya overhead pabrik yang dikeluarkan dalam proses produksi [1].

Biaya produksi atau Harga Pokok Produksi (Cost of Goods Manufactured) merupakan kumpulan dari biaya-biaya yang dikeluarkan 
untuk memperoleh dan mengolah bahan baku sampai menjadi barang jadi. Penentuan harga pokok produksi tergantung dari tipe perusahaan tersebut dalam mengolah bahan baku menjadi produk jadi. Apabila perusahaan berproduksi secara terus menerus atau disebut dengan produksi massa maka menggunakan metode harga pokok proses. Sedangkan kalau perusahaan yang melakukan produksi secara pesanan maka menggunakan metode harga pesanan.

\subsection{Metode Perhitungan Harga Pokok Produksi}

Adapun metode Pengumpulan Harga Pokok Produksi tersebut [2] adalah sebagai berikut:

a. Metode Harga Pokok Pesanan (Job Order Cost Method)

Metode harga pokok pesanan merupakan metode pengumpulan harga pokok produk dimana biaya dikumpulkan untuk setiap pesanan atau kontrak atau jasa secara terpisah, dan setiap pesanan atau kontrak dapat dipisahkan identitasnya. Pengolahan produk akan dimulai setelah datangnya pesanan dari langganan/pembeli melalui dokumen pesanan penjualan (sales order), yang memuat jenis dan jumlah produk yang dipesan, spesifikasi pesanan, tanggal pesanan diterima dan harus diserahkan.

b. Metode Harga Pokok Proses (Process Cost Method)

Metode harga pokok proses merupakan metode pengumpulan harga pokok produk dimana biaya dikumpulkan untuk setiap satuan waktu tertentu, misalnya: bulan, triwulan, semester, tahun. Pada metode harga pokok proses perusahaan menghasilkan produk yang homogen, bentuk bersifat standar, dan tidak tergantung spesifikasi yang diminta oleh pembeli. Tujuan produksi untuk mengisi persediaan yang selanjutnya akan dijual kepada pembeli, oleh karena itu sifat produk homogen dan bentuknya standar maka kegiatan dilakukan secara kontinyu atau terusmenerus

\subsection{Metode Perhitungan Harga Pokok Proses}

Metode harga pokok proses adalah metode pengumpulan harga pokok (biaya produksi) yang berdasarkan atas proses atau departemen untuk suatu periode tertentu, biasanya satu bulan. Biaya bahan baku, biaya tenaga kerja dan biaya produksi tidak langsung (overhead) yang dibebankan, dibebankan pada rekening-rekening barang dalam proses setiap departemen. Pada setiap akhir . periode, total harga pokok (biaya produksi) yang terjadi pada suatu departemen dibagi dengan jumlah unit yang selesai diproduksi akan menghasilkan harga pokok per unit departemen yang bersangkutan. Karakteristik Penentuan Biaya proses menurut [3] sebagai berikut :

a. Aktivitas produksi bersifat terus menerus.

b. Produksi bersifat massa dengan tujuan mengisi persediaan yang siap dijual.

c. Produk yang dihasilkan dalam suatu departemen atau pusat biaya relative homogeny dan berdasarkan standar.

d. Biaya dibebankan kesetiap unit dengan membagi total biaya yang dibebankan ke pusat biaya dengan total unit yang diproduksi.

e. Pengumpulan biaya dilakukan berdasarkan periode waktu tertentu

\subsection{Penelitian Sebelumnya}

Penelitian yang dilakukan oleh Diah memberikan pernyataan bahwa apa yang Berdasarkan dari pembahasan diatas maka dapat diambil kesimpulan sebagai berikut: PT. Persada menggunakan perhitungan harga pokok produksi yang masih sederhana. Karena dalam perhitungan harga pokok produksi menggunakan tingkat perubahan harga pasar [4].

Penelitian lain yang terkait dengan penentuan harga pokok produksi yang dilakukan oleh Lasena [5] bahwa Perhitungan berdasarkan metode variabel costing yang dibuat oleh penulis didapatkan hasil yang berbeda dengan perhitungan perusahaan menggunakan full costing. Perbedaan utama antara metode perhitungan full costing yang digunakan dengan metode variabel costing terletak pada perlakuan biaya overhead pabrik. Dimana dalam metode full costing menggunakan biaya overhead tetap dan biaya variabel, sedangkan di metode variabel costing hanya menggunakan biaya overhead variable.

Penelitian yang Dilakukan oleh [6] Dalam penentuan harga pokok produksi perusahaan memasukkan semua biaya ke dalam biaya produksi yaitu biaya bahan baku, tenaga kerja langsung, overhead pabrik, perlengkapan kantor dan transportasi total harga pokok produksi perusahaan Rp. 55.738.625.-. Berdasarkan perhitungan harga pokok produksi dengan metode full costing diperoleh harga pokok produksilebih rendah $\mathrm{Rp}$. 55.218.625,- terdapat selisih Rp.520.000.Perbedaan nilai yang dihasilkan disebabkan 
oleh pembebanan biaya overhead pabrik pada perusahaan lebih tinggi dari pembebanan overhead dengan metode full costing.

\section{METODE PENELITIAN}

\subsection{Pengambilan Data}

a. Metode Observasi

Mengetahui proses-proses yang terjadi di perusahaan dan data yang diperoleh tentang proses produksi batik.

b. Metode Wawancara

Menanyakan tahapan produksi dan bahan produksi yang digunakan dalam proses produksi.

c. Metode Kepustakaan

Mengumpulkan data dan informasi serta pengetahuan yang berasal dari buku mengenai metode harga pokok produksi dan penelitian yang terkait dengan metode harga pokok produksi.

buku pembahasan pengendalian produksi, semua informasi tentang produksi dan sirkulasinya

\subsection{Analisa Sistem}

Analisa ini dilakukan untuk mengetahui apa saja kebutuhan yang dibutuhkan untuk merancang program untuk menentukan pengendalian produksi dan bagaimana kerja dari program yang dirancang seperti kerja dari input, proses, dan outputnya. Sehingga sistem perhitungan harga pokok produksi yang di rancang menjadi lebih mudah digunakan dan dipahami. Penulis akan membuat aplikasi sistem perhitungan harga pokok produksi dengan metode harga pokok proses yang terdiri dari:

a. Data master yaitu data bahan baku, biaya overhead pabrik, biaya tenaga kerja.

b. Pengolahan biaya barang, perhitungan harga pokok produksi dan harga jual

c. Laporan-laporan yang dibutuhkan.

\subsection{Perancangan Sistem}

Perancangan sistem dilakukan dengan menggunakan tahapan yang terdiri dari:

a. Bagan Alir Dokumen adalah menggambarkan aliran dokumen / informasi antar bagian / satuan organisasi disalam organisasi. Bagan ini menjelaskan dari bagian/unitmana suatu dokumen berasal serta ke bagian/unit mana saja dokumen tersebut didistribusikan, sekaligus menunjukkan jumlah (lembar) salinan dokumen yang diperlukan.

b. Diagram konteks adalah diagram yang terdiri dari suatu proses dan menggambarkan ruang lingkup suatu sistem. Diagram Konteks ini merupakan bagian dari level tertinggi dari DFD (Data Flow Diagram) yang menggambarkan seluruh input ke suatu sistem atau output dari sistem. la akan memberi gambaran mengenai keseluruhan dari sistem. Sistem dibatasi oleh Boundary (dapat digambarkan dengan garis putus). Dalam Diagram Konteks hanya terdapat satu proses saja, tidak boleh ada stroke di dalam diagram konteks.

c. HIPO (Hierarchy Input Process Output) adalah alat bantu yang digunakan untuk membuat spesifikasi program yang merupakan struktur yang berisi diagram dimana didalam program ini berisi input yang diproses dan menghasilkan output. HIPO adalah alat yang digunakan sebagai dokumentasi program dan sebagai alat desain dan teknik dokumentasi dalam siklus pengembangan sistem.

d. DAD (Diagram Alir Data) adalah gambaran arus data didalam suatu organisasi. Diagram ini dipakai untuk melukiskan komponen-komponen suatu sistem, arus data diantara komponen-komponen sistem tersebut.

\subsection{Implementasi Sistem}

Implementasi ini dilakukan untuk mengetahui spesifikasi komputer untuk menjalankan program dan program apa saja yang di butuhkan. Merupakan tahap penelitian yang dilakukan untuk mempraktekkan langsung hasil dari analisa yang bertujuan untuk menguji kebenaran sistem yang dirancang mulai dari input master, transaksi dan output laporan data. Software yang dipakai yaitu Visual Basic Net dengan database Sql Server.

\subsection{Pengujian Sistem}

Proses selanjutnya adalah pengujian program, program yang telah dibangun akan diuji untuk mengetahui apakah program tersebut berjalan dengan benar dan sesuai dengan perancangan yang dilakukan. Setelah program selesai maka tahap selanjutnya adalah tahapan pemeliharaan. Untuk pengujian aplikasi ini menggunakan cara aplikasi langsung mendata data langsung dari kondisi produksi yang dilakukan. Black box testing adalah pengujian yang didasarkan pada pengecekan terhadap detail perancangan, menggunakan struktur kontrol dari desain program secara prosedural untuk membagi pengujian ke dalam beberapa kasus 
pengujian. Secara sekilas dapat diambil kesimpulan black box testing merupakan petunjuk untuk mendapatkan program yang benar secara 100\%. Pengujian program digunakan untuk mengetahui Sistem Pendukung Keputusan valid atau tidak.

\section{HASIL DAN PEMBAHASAN}

\subsection{Perancangan Sistem}

Bagan alir dokumen merupakan bagan alir yang menunjukkan arus dari formulir dan laporan termasuk bagian-bagiannya. Bagan alir ini dibuat untuk mempermudah dalam memahami prosedur Perhitungan Harga Pokok Produksi dengan Metode Harga Pokok Proses pada usaha Batik. Bagan alir dokseperti pada Gambar 1.

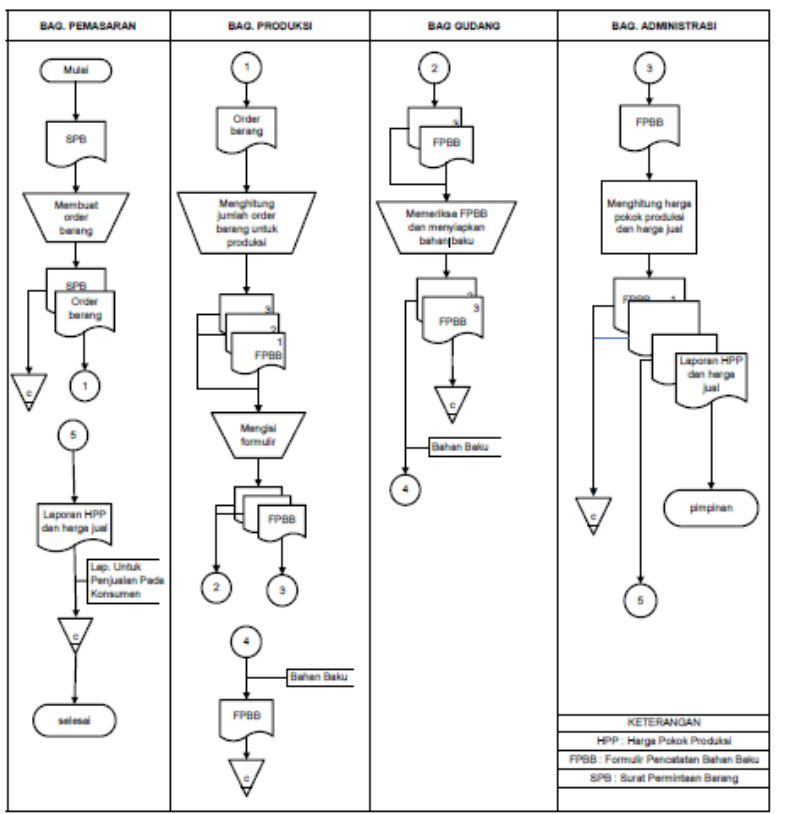

Gambar 1. Bagan Alir Dokumen

Diagram konteks adalah suatu bagan yang menggambarkan aliran data dijabarkan secara global yang menggambarkan aliran data bersumber pada Bagian Produksi, Bagian Administrasi dan Bagian Gudang yang selanjutnya diolah dalam proses pengolahan data untuk menghasilkan informasi. Pada Sistem Komputerisasi Perhitungan Harga Pokok Produksi Proses pada Batik Nur Hasida Sragen, dimulai dengan mengolah data-data yang dimasukkan oleh Bagian Produksi. Suatu konteks diagram selalu mengandung satu proses saja. Proses ini mewakili proses dari seluruh sistem yang menggambarkan hubungan masukan atau keluaran menjadi satu kesatuan pada Sistem Komputerisasi Perhitungan Harga Pokok Produksi. Adapun kontek diagram dapat dilihat seperti pada Gambar 2.

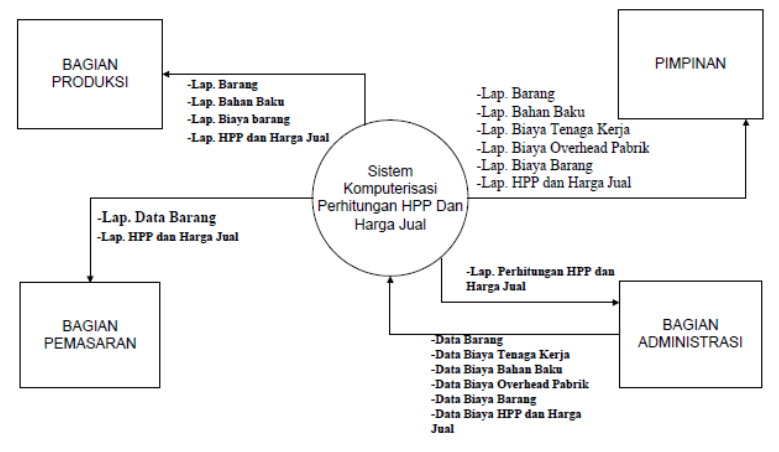

\section{Gambar 2. Konteks Diagram}

Bagan berjenjang (HIPO) ini digunakan untuk mempersiapkan penggambaran Diagram Arus Data untuk menuju level-level lebih bawah lagi. Bagan berjenjang dapat digambarkan dengan menggunakan notasi proses yang digunakan di Diagram Arus Data.

Untuk aplikasi sistem pengolahan data, proses-proses yang ada dapat digambarkan sesuai dengan jenjangnya, dimana jenjang tersebut terdiri dari tiga bagian yaitu Top Level, Level 0, dan Level 1 seperti pada Gambar 3.

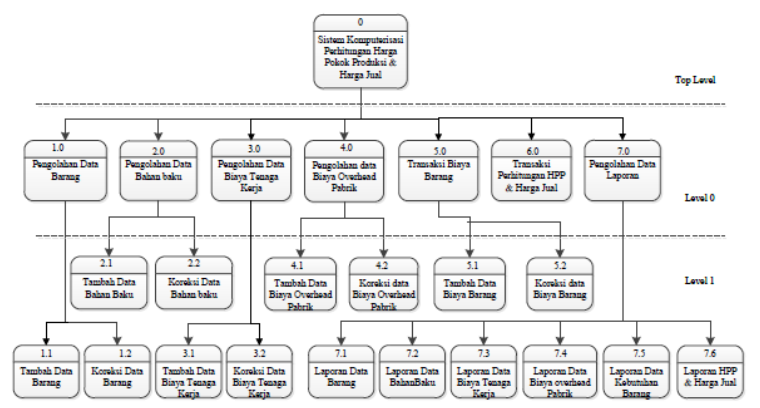

Gambar 3. HIPO

Diagram alir data ini merupakan diagram yang digunakan untuk menggambarkan sistem pencatatan bahan sekaligus Perhitungan Harga Pokok Produksi dan Harga Jual. Hal-hal yang terkait dengan diagram alir data ini antara lain : Kesatuan Luar, Proses Data, dan Media Simpanan Data. Kesatuan Luar yang terkait dalam pencatatan transaksi Perhitungan Harga Pokok Produksi dengan metode Harga Pokok Proses pada usaha Batik pada Bagian Produksi dan Pimpinan.

Data yang digunakan meliputi Data Barang, Data Bahan Baku, Data Biaya Tenaga Kerja, dan Data Biaya Overhead Pabrik. Sedangkan proses yang terjadi meliputi pengolahan Data Barang, Pengolahan Data Bahan Baku, Pengolahan 
Data Biaya Tenaga Kerja, Laporan Data Kebutuhan Barang, Laporan Harga Pokok Produksi dan Harga Jual. Sedanngkan tabel yang diperlukan adalah: Bahan, Barang, BTK, BOP, Kebutuhan, Transaksi yang dapat dilihat pada Gambar 4.

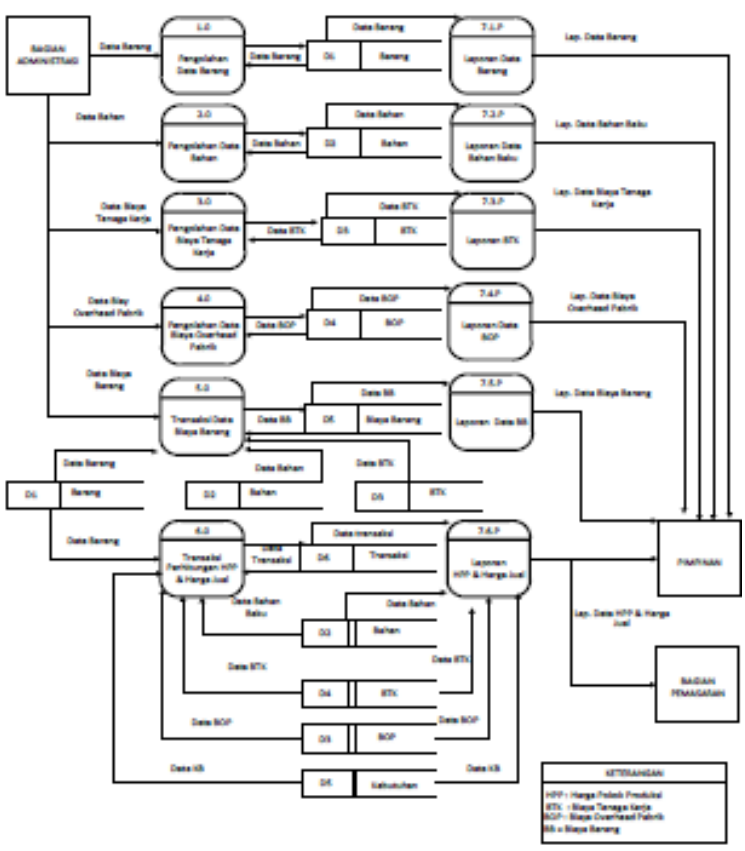

Gambar 4. DAD

\subsection{Implementasi}

Input Data Biaya Barang digunakan untuk menambah data biaya barang atau mengupdate data biaya barang yang sudah ada. Terdapat tombol Tambah, Simpan, Hapus dan Keluar. Untuk menambah data tertentu tekan tombol Tambah kemudian isikan data satu per satu, setelah selesai tekan Simpan, untuk mengkoreksi data tekan tombol Ubah, untuk menghapus data tekan tombol Hapus dan tekan tombol Keluar untuk kembali ke Menu Utama, seperti pada Gambar 5.

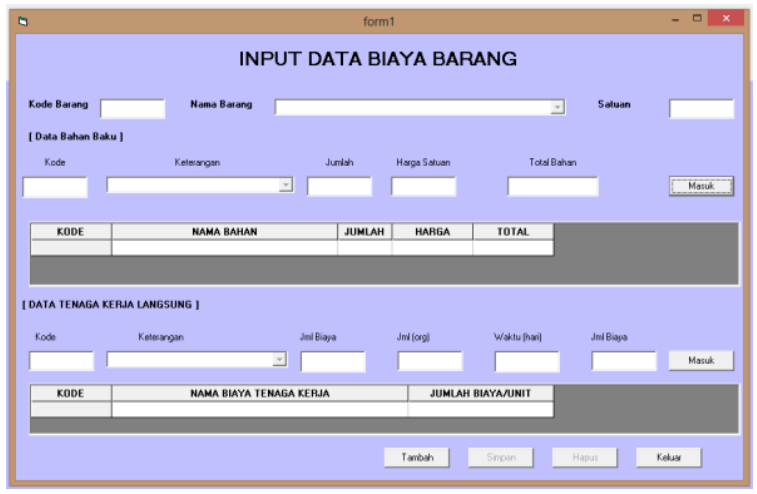

Gambar 5. Input data biaya barang

Setelah melakukan input data biaya barang Menu Transaksi hanya terdiri satu submenu, yaitu Transaksi Perhitungan HPP dan Harga Jual yang digunakan untuk mengolah data transaksi dala, memproduksi batik pada Batik Nur Hasida Sragen. Terdapat tombol Tambah, Simpan, Batal dan Keluar. Bila ingin menambah data klik tombol Tambah setelah selesai mengisi data kemudian tekan tombol Simpan, tekan tombol Batal jika ingin membatalkan pengisian data, tekan tombol Cari untuk mencari data berdasarkan kunci pada tabel di database, dan tekan tombol Keluar untuk kembali ke Menu Utama seperti pada Gambar 6.

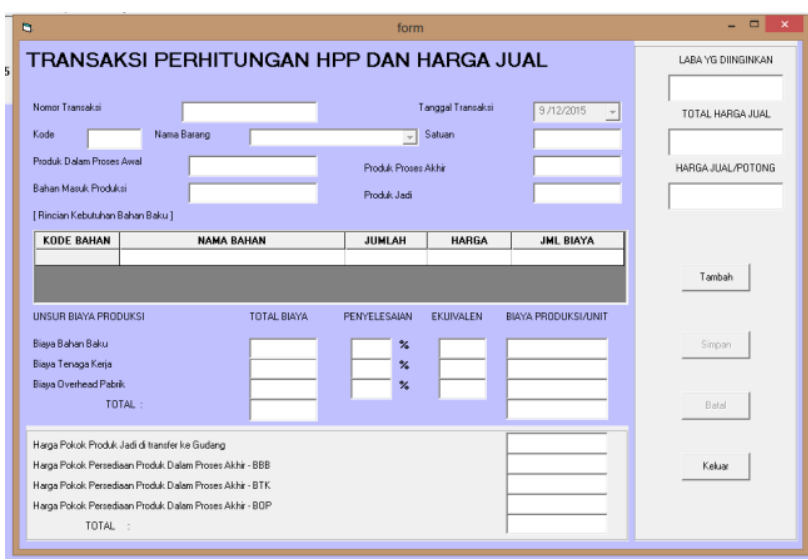

Gambar 6. Transaksi perhitungan harga pokok

Adapun laporan yang dihasilkan dalam aplikasi perhitungan harga pokok produksi berupa laporan data HPP dan harga jual seperti dalam gambar 7 berikut.

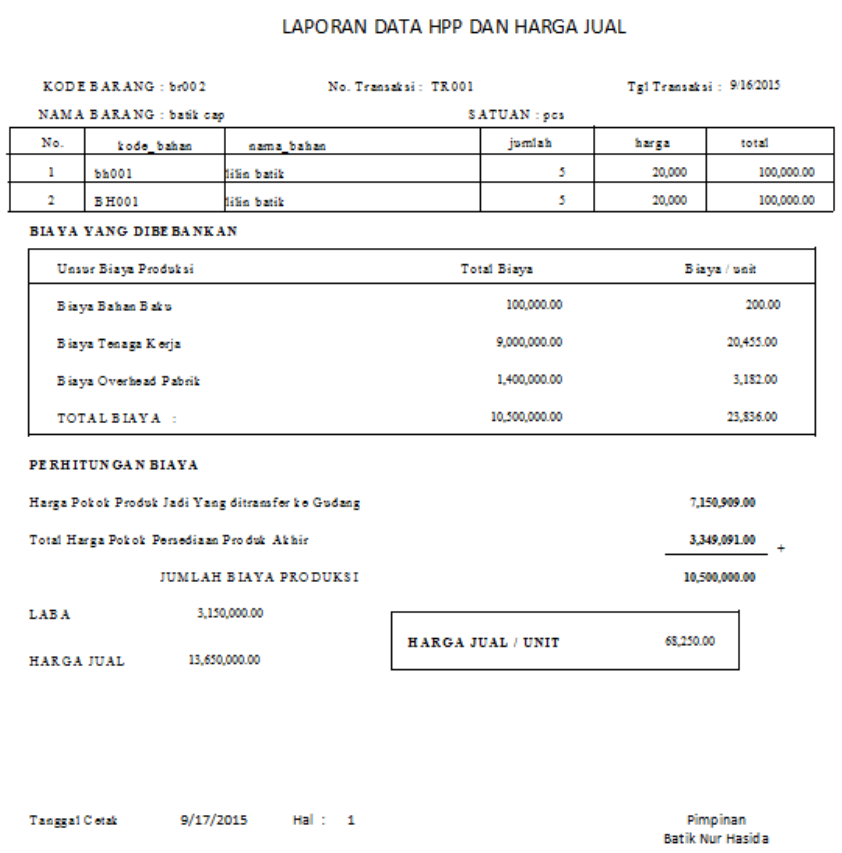

Gambar 7. Laporan HPP dan Harga jual

\subsection{Pengujian}

Teknik pengujian yang digunakan adalah Black-box testing yaitu pengujian yang 
menunjukkan tentang cara beroperasinya sebuah aplikasi. Black-box testing ini memfokuskan pada keperluan fungsional dari sebuah software. Pengujian aplikasi dilakukan dengan metode Black-box untuk mengetahui apakah semua fungsi berjalan sesuai. Tabel black-box dapat dilihat pada Tabel 1-3.

Tabel 1. Hasil Uji Black-box File

\begin{tabular}{|c|c|c|}
\hline Halaman & Yang diuji & Hasil \\
\hline $\begin{array}{c}\text { Konfigurasi } \\
\text { sistem }\end{array}$ & $\begin{array}{c}\text { Klik "edit" } \\
\text { perubahan data } \\
\text { profil } \\
\text { perusahaan }\end{array}$ & $\begin{array}{c}\text { Berjalan } \\
\text { dengan } \\
\text { baik }\end{array}$ \\
\hline Login & $\begin{array}{c}\text { Klik "login" } \\
\text { pemakai }\end{array}$ & $\begin{array}{c}\text { Berjalan } \\
\text { dengan } \\
\text { baik }\end{array}$ \\
\hline
\end{tabular}

Tabel 2. Hasil Uji Black-box Master

\begin{tabular}{|c|c|c|}
\hline Halaman & Yang diuji & Hasil \\
\hline $\begin{array}{c}\text { Tombol } \\
\text { "tambah" }\end{array}$ & $\begin{array}{c}\text { klik tombol } \\
\text { "tambah" }\end{array}$ & $\begin{array}{c}\text { Berjalan } \\
\text { dengan } \\
\text { baik }\end{array}$ \\
\hline $\begin{array}{c}\text { Tombol } \\
\text { "cari" }\end{array}$ & klik tombol "cari" & $\begin{array}{c}\text { Berjalan } \\
\text { dengan } \\
\text { baik }\end{array}$ \\
\hline $\begin{array}{c}\text { Tombol } \\
\text { "hapus" }\end{array}$ & $\begin{array}{c}\text { Klik tombol } \\
\text { "hapus" }\end{array}$ & $\begin{array}{c}\text { Berjalan } \\
\text { dengan } \\
\text { baik }\end{array}$ \\
\hline $\begin{array}{c}\text { Tombol } \\
\text { "simpan" }\end{array}$ & $\begin{array}{c}\text { Klik tombol } \\
\text { "simpan" }\end{array}$ & $\begin{array}{c}\text { Berjalan } \\
\text { degan } \\
\text { baik }\end{array}$ \\
\hline $\begin{array}{c}\text { Tombol } \\
\text { "keluar" }\end{array}$ & Klik tombol & $\begin{array}{c}\text { Berjalan } \\
\text { dengan } \\
\text { baik }\end{array}$ \\
\hline
\end{tabular}

Tabel 3. Hasil Uji Black-box Menu transaksi

\begin{tabular}{|c|c|c|}
\hline Halaman & Yang diuji & Hasil \\
\hline $\begin{array}{c}\text { Tombol } \\
\text { tambah" }\end{array}$ & $\begin{array}{c}\text { klik tombol } \\
\text { "tambah" }\end{array}$ & $\begin{array}{c}\text { Berjalan } \\
\text { dengan } \\
\text { baik }\end{array}$ \\
\hline $\begin{array}{c}\text { Tombol } \\
\text { "batal" }\end{array}$ & $\begin{array}{c}\text { Klik tombol } \\
\text { "batal" }\end{array}$ & $\begin{array}{c}\text { Berjalan } \\
\text { dengan } \\
\text { baik }\end{array}$ \\
\hline $\begin{array}{c}\text { Tombol } \\
\text { "simpan" }\end{array}$ & $\begin{array}{c}\text { Klik tombol } \\
\text { "simpan" }\end{array}$ & $\begin{array}{c}\text { Berjalan } \\
\text { degan baik }\end{array}$ \\
\hline $\begin{array}{c}\text { Tombol } \\
\text { "keluar" }\end{array}$ & $\begin{array}{c}\text { Klik tombol } \\
\text { "keluar" }\end{array}$ & $\begin{array}{c}\text { Berjan } \\
\text { dengan } \\
\text { baik }\end{array}$ \\
\hline
\end{tabular}

Berdasarkan pengujian Black Box yang telah dilakukan didapat hasil yang ditunjukan pada tabel 1 - 3 yang menunjukan bahwa semua menu dapat berjalan dengan baik. Begitupun semua menu pilihan yang ada pada menu Informasi yang meliputi 6 marshalling signals semua berjalan dengan baik.

\section{KESIMPULAN}

Perancangan sistem yang terdiri dari Diagram Konteks (Context Diagram), Hierarchy Input Proses Output (HIPO), relasi Antar Tabel, Diagram Arus Data (DAD), Desain Input dan Desain Output. Dan aplikasi yang dibangun merupakan aplikasi perhitungan harga pokok produksi dengan metode harga pokok proses yang memiliki menu yang terdiri dari File, Master, Transaksi, Laporan dan Utility. Dari aplikasi tesebut telah dilakukan pengujian dengan menggunakan uji black box dan dinyatakan dapat berjalan dengan baik semua fungsi yang digunakan dari masing-masing menu.

\section{DAFTAR PUSTAKA}

[1] Muyadi, Akuntansi Biaya Edisi ke-13, Yogyakarta: UPP STIE YKPN, 2014.

[2] Supriyono, Perencanaan dan Pengendalian serta Pengmabilan Keputusan, Yogyakarta: BPFE, 2013.

[3] Bustami B \& Nurlela, Akuntansi Biaya, Jakarta: Mitra Wahana Media, 2013.

[4] Diah Indah Sari, "Perhitungan Harga Pokok Proses Pada PT Persada," Moneter, vol. 2, no. 5, pp. 163-170, 2018.

[5] Sitty Rahmi Lasena, "Analisis Penentuan Harga Pokok Produksi Pada PT. Dimembe Nyiur Agripro," Jurnal EMBA, vol. 1, no. 3, pp. 585-592, Juni 2013.

[6] H. Batubara, "Penentuan Harga Pokok Produksi Berdasarkan Metode Fullcosting pada Pembuatan Etalase Kaca dan Alumunium di UD Istana Alumunium Manado," $E M B A$, vol. 3, no. 1, pp. 217224, 2013. 